\title{
WEBINAR SOSIALISASI COVID-19 DAN ISOLASI MANDIRI VIA ZOOM DI DESA PESANGGRAHAN KECAMATAN SOLEAR KABUPATEN TANGERANG
}

\author{
Ratna Sari Dewi ${ }^{\mathrm{a}, \mathbf{1}}$, Zahran Hafiidh Kenvisyah ${ }^{\mathbf{b}, \mathbf{2}}$ \\ aProdi PPKn; FKIP, Universitas Sultan Ageng Tirtayasa, Serang* \\ ${ }^{b}$ Mahasiswa Teknik Kimia; Fakultas Teknik, Universitas Sultan Ageng Tirtayasa, Cilegon \\ ${ }^{1}$ ratna@ untirta.ac.id; ${ }^{2}$ zahran.hafi11@gmail.com \\ *korespondensi penulis
}

Naskah diterima: 25 November 2020 , direvisi: 29 Desember 2020 , disetujui: 24 Februari 2021

\begin{abstract}
Abstrak
Pengabdian kepada masyarakat merupakan salah satu Tri Dharma Perguruan Tinggi .guna melibatkan perguruan tinggi untuk memecahkan masalah yang ada di masyarakat yang salah satunya melalui kegiatan kuliah kerja mahasiswa (KKM). Meningkatnya tren kasus virus COVID-19 di Indonesia mengakibatkan kegiatan KKM tahun ini dilakukan secara daring. COVID-19 merupakan wabah pandemi yang melanda di berbagai negara dan menjadi salah satu bentuk kekhawatiran bagi masyarakat. Saat ini, muncul banyak varian mutasi wabah COVID-19 yang mengakibatkan risiko penyebaran meningkat. Banyak fasilitas kesehatan di Indonesia saat ini berada dalam kapasitas yang penuh, sehingga untuk masyarakat yang mengalami gejala COVID-19 ringan diarahkan untuk menjalani isolasi mandiri di rumah masing-masing. Kelompok 37 KKM Tematik UNTIRTA mengadakan program kerja webinar sosialisasi COVID-19 dan isolasi mandiri. Kesimpulan dari kegiatan ini adalah terlaksananya webinar COVID-19 dan isolasi mandiri yang menargetkan masyarakat umum dengan pemateri dari dr. Taufik Nugraha, Dokter Puskesmas Cikuya dan hadirnya perwakilan Desa Pasanggrahan serta Camat Kecamatan Solear. Tujuan dari program kerja ini adalah untuk mengedukasi masyarakat umum terkait COVID-19 serta prosedur untuk menjalani isolasi mandiri yang benar. Hasil webinar telah memberikan tambahan pemahaman terhadap masyarakat khususnya warga Desa Pesanggrahan Kecamatan Solear Kabupaten Tangerang. Di sarankan kepada aparat pemerintahan Desa agar tidak bosan untuk mengedukasi masyarakatnya mengenai Covid 19.
\end{abstract}




\begin{abstract}
Community service is one of the Tri Dharma of Higher Education in order to involve universities to solve problems that exist in the community, one of which is through student work activities (KKM). The increasing trend of COVID-19 virus cases in Indonesia has resulted in this year's KKM activities being carried out online. COVID-19 is a pandemic outbreak that has hit various countries and is a form of concern for the public. Currently, there are many variants of the COVID-19 outbreak mutation that result in an increased risk of spread. Many health facilities in Indonesia are currently at full capacity, so people who experience mild COVID19 symptoms are directed to undergo independent isolation at their respective homes. The 37 UNTIRTA Thematic KKM group held a webinar work program on COVID19 socialization and self-isolation. The conclusion of this activity is the implementation of a COVID-19 webinar and self-isolation targeting the general public with a speaker from dr. Taufik Nugraha, Doctor of the Cikuya Health Center and the presence of representatives of Pasanggrahan Village and the Sub-district Head of Solear. The purpose of this work program is to educate the general public regarding COVID-19 and the procedures for proper self-isolation. The results of the webinar have provided additional understanding to the community, especially the residents of Pesanggrahan Village, Solear District, Tangerang Regency. It is recommended that village government officials do not get bored educating their people about Covid 19.
\end{abstract}

Keywords: Community service; Webinar ; Covid 19

\section{PENDAHULUAN}

Sejak akhir tahun 2019 hingga sampai saat ini, dunia tengah dilanda kasus pandemi jenis penyakit baru, yaitu Covid-19. Kasus ini diawali pada 31 Desember 2019, dimana Covid 19 ini pertama kali di temukan di wuhan, Propinsi Hubei, China. Setelah itu menyebar ke berbagai negara.

Pada tanggal 2 Maret 2020 di Indonesia mulai terdeteksi adanya 2 kasus positif COVID-19 (Burhan, E., 2020). Hingga saat ini, COVID-19 telah menyebar di semua provinsi di Indonesia. Terhitung pertanggal 8 Agustus 2021 jumlah kasus yang positif COVID-19 di Indonesia yang terkonfirmasi sejumlah 3.666.031 kasus. Banten merupakan provinsi paling barat pulau jawa. Pada provisi ini jumlah kumulatif kasus COVID-19 sampai dengan 8 Agustus 2021 terhitung sebanyak 118.353 kasus dengan jumlah kasus meninggal sebanyak 2.599 kasus (kemkes.go.id). Kabupaten Tangerang merupakan bagian dari provinsi Banten. Perkembangan kasus COVID-19 di Kabupaten Tangerang sampai tanggal 8 Agustus 2021 dengan jumlah kasus sebanyak 25.426 kasus dan keterangan meninggal sebanyak 385 korban (Dinkes Kab Tangerang, 2021).

Ancaman penyebaran penyakit COVID-19 yang semakin meluas dan jumlah korban maupun orang yang positif terjangkit semakin bertambah dikarenakan karakteristik penularannya yang cepat membuat banyak 
ahli dan pemerintah menetapkan atau membuat segala peraturan terkait upaya pencegahan penyebaran COVID-19. Safrizal, et.al (2020) menjelaskan prioritas yang utama dalam kebijakan pemerintah adalah proses pengendalian dan pencegahan penyebaran Covid - 19.

Tujuan dari upaya pencegahan dan pengendalian Virus ini adalah untuk memutus mata rantai penyebaran penyakit COVID-19 sehingga menurunkan kurva jumlah korban dan orang yang positif terinfeksi virus SARS-COV-2 penyebab COVID-19. Bebebrapa hal yang dilakukan sebagia upaya pengendalian penyebaran COVID-19 menurut Menkominfo RI (2020) antara lain : Rajin mencuci tangan sabun dan air mengalir; menerapkan etika batuk dan bersin dengan menutup mulut menggunakan tisu atau bagian dalam siku; meminimalisir kontak langsung dengan orang lain dan menyentuh area wajah terutama mata, mulut, dan hidung; menghindari tempat yang ramai dengan lebih sering berada di rumah dan bepergian seperlunya; tanggap terhadap kesehatan diri terutama apabila mengalami batuk, flu, demam dan sulit untuk bernafas, untuk segera minum obat dan pergi ke dokter; rajin menggunakan masker dengan cara yang tepat, menjaga jarak aman terutama di tempat-tempat umum; dan yang terpenting adalah selalu menjaga kebersihan diri, barang-barang dan tempat tinggal dan sekitarnya.

\section{KKM (Kuliah Kerja Mahasiswa)} merupakan kegiatan pengabdian mahasiswa yang dilakukan menjelang semester akhir yaitu pada semester 7 sebagai sarana untuk mahasiswa belajar mengabdi dan bermasyarakat serta menjadi mata kuliah wajib di UNTIRTA. Pada masa pandemi COVID-19 ini, sistem KKM yang diterapkan berbeda dengan biasanya yaitu dengan sistem KKM daring dan kegiatan yang dilakukan bertemakan seputar COVID-19 dan bertujuan untuk memutus mata rantai penyebaran COVID-19. Selain itu, salah satu kebijakan di KKM daring ini yaitu anggota KKM dipilih dari kota dan kecamatan yang sama serta membatasi kegiatan atau interaksi langsung dengan masyarakat. Kelompok KKM 37 merupakan kelompok KKM yang berdomisili di Kabupaten Tangerang dan Kecamatan Solear. Kegiatan program kerja yang dilakukan dalam rangka mengedukasi masyarakat umum yaitu dengan webinar sosialisasi COVID-19 dan isolasi mandiri.

Pada saat ini, virtual meeting sudah banyak dilakukan oleh perusahaan/institusi di seluruh dunia untuk mencapai suatu tujuan tertentu yang diinginkan oleh perusahaan/institusi karena seminar konvensional sulit untuk dilakukan. Lebih lanjut, Goldblatt (2013) menjelaskan digital event dapat ditentukan berdasarkan 
pengalaman pelaksanaanya, mulai dari event yang relatif berjalan selama satu hingga dua jam seperti webinar hingga event yang berjalan berhari-hari, selama pelaksanaan digital event itu berjalan dengan face-to-face meetings. Webinar berasal dari kata 'web dan 'seminar' yang yang merupakan seminar, rapat, dan presentasi yang dilakukan dengan cara online/daring. Webinar merupakan seminar yang dilakukan dengan cara online/daring dan dibuat secara interaktif. Webinar biasanya disertai beberapa video, konten, dan slide presentasi dalam pelaksanaanya guna memberikan informasi dengan lebih jelas kepada peserta webinar.

\section{METODE}

Di Indonesia, pendidikan adalah salah satu yang terkena dampak Pandemi COVID-19. Metode yang dilakukan adalah penyuluhan. Mahasiswa KKM 37 Universitas Sultan Ageng Tirtayasa, melakukan webinar sosialisasi COVID-19 dan isolasi mandiri. Webinar ini bertujuan untuk mengedukasi masyarakat Desa Pesanggrahan Kecamatan Solear Kabupaten Tanggerang dan masyarakat umum tentang COVID-19 serta langkah tepat untuk menjalani isolasi mandiri. Kegiatan pengabdian ini diawali dengan 3 tahap yaitu perencanaan, dilanjutkan dengan pelaksanaan, dan monitoring. Berikut deskripsi untuk masing-masing langkah : a. Tahapan Perencanaan

Tahap Pertama yaitu menentukan judul dan topik kegiatan webinar lalu membuat konsep serta teknis kegiatan. Kelompok KKM 37 mengundang Kepala Desa Pasanggrahan dan Camat Kecamatan Solear untuk memberikan sambutan serta dr. Taufik Nugraha selaku dokter Puskesmas Cikuya sebagai narasumber.

b. Tahapan Pelaksanaan

Tahap kedua untuk tahap pelaksanaan adalah pelaksanaan webinar sosialisasi COVID-19 dan isolasi mandiri melalui platform Zoom. Pelaksanaan webinar ini dihadiri oleh masyarakat umum

c. Tahapan Monitoring

Tahap Ketiga, tahapan akhir pengabdian ini dilakukannya evaluasi pelaksanaan kegiatan.

\section{PEMBAHASAN}

Penyebab COVID 19 adalah virus corona yang reseptornya berada pada sistem pernafasan. Coronavirus merupakan virus yang memiliki RNA strain tunggal positif, virus ini tergolong ke dalam ordo Nidovirales, famili Coronaviridae subfamili Orthocoronavirinae, yang memiliki "crown" pada permukaannya. Virus ini umumnya ditemukan pada hewan seperti unta, sapi, kucing dan kelelewar (Yuliana, 2020) 

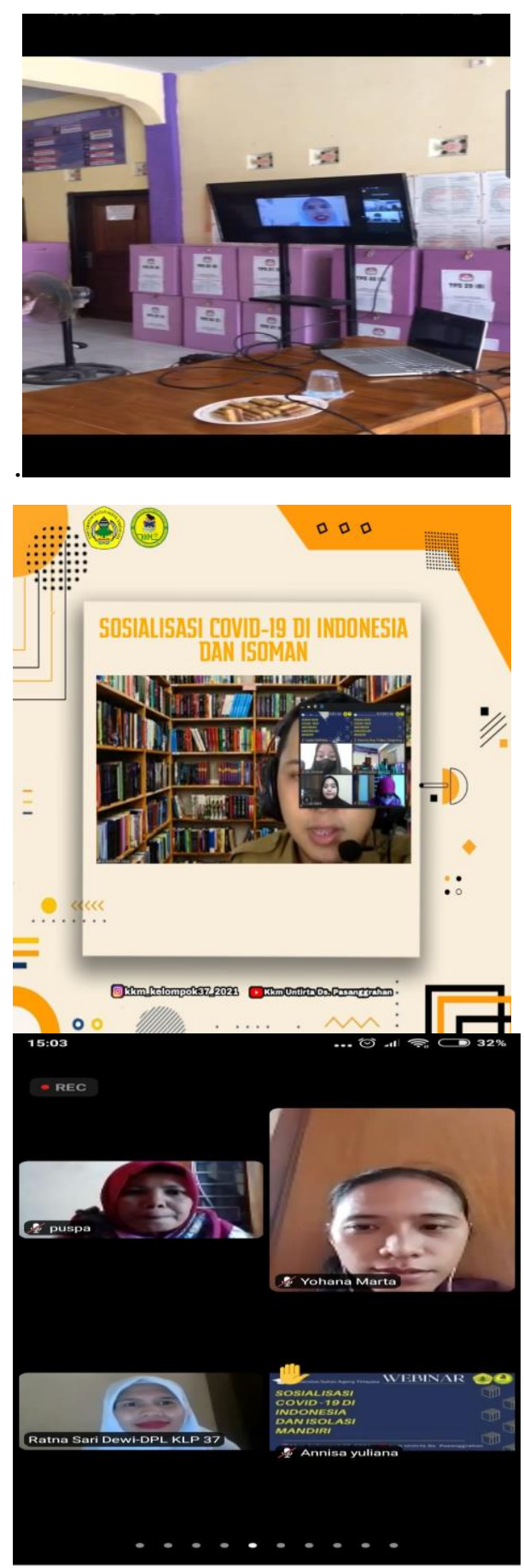

Gambar 1. Kegiatan webinar Sosialisasi Covid-19 dan Isoman

Diagnosis penyakit ini harus mencakup semua jenis infeksi virus pernapasan [influenza, parainfluenza, virus pernapasan syncytial (RSV), adenovirus, metapneumovirus manusia, non COVID-19 coronavirus], organisme atipikal (mikoplasma, klamidia) dan infeksi bakteri. Tidak mungkin membedakan COVID-19 dari infeksi ini secara klinis atau melalui tes laboratorium rutin. Oleh karena itu sejarah perjalanan menjadi penting. Namun, saat epidemi menyebar, riwayat perjalanan menjadi tidak relevan. (Sinhal, 2020)

Pandemi juga telah mengakibatkan hilangnya mata pencaharian karena penutupan yang berkepanjangan, yang memiliki efek beriak pada ekonomi global. Meskipun kemajuan substansial dalam penelitian klinis telah mengarah pada pemahaman dan pengelolaan COVID-19, membatasi penyebaran virus ini dan variannya telah menjadi masalah yang semakin mengkhawatirkan, karena SARSCoV- 2 terus mendatangkan malapetaka di seluruh dunia, dengan banyak negara mengalami gelombang kedua atau ketiga wabah penyakit virus ini terutama disebabkan oleh munculnya varian virus mutan.

Seperti virus RNA lainnya, SARSCoV-2, saat beradaptasi dengan inang manusia baru mereka, rentan terhadap evolusi genetik dengan perkembangan mutasi dari waktu ke waktu, menghasilkan varian mutan yang mungkin memiliki karakteristik berbeda dari strain leluhurnya. Beberapa varian SARS-CoV-2 telah 
dijelaskan selama pandemi ini, di antaranya hanya beberapa yang dianggap sebagai varian yang menjadi perhatian (VOC) oleh WHO, mengingat dampaknya terhadap kesehatan masyarakat global. Berdasarkan pembaruan epidemiologi terbaru oleh WHO, pada 22 Juni 2021, empat VOC SARS-CoV2 telah diidentifikasi sejak awal pandemi:

1. Alpha (B.1.1.7): varian kekhawatiran pertama yang dijelaskan di Inggris Raya (UK) pada akhir Desember 2020

2. Beta (B.1.351): pertama kali dilaporkan di Afrika Selatan pada Desember 2020

3. Gamma(P.1): pertama kali dilaporkan di Brasil pada awal Januari 2021

4. Delta (B.1.617.2): pertama kali dilaporkan di India pada Desember 2020

Terlepas dari kecepatan pengembangan vaksin yang belum pernah terjadi sebelumnya terhadap pencegahan COVID-19 dan upaya vaksinasi massal global yang kuat, kemunculan varian baru SARS-CoV-2 ini mengancam untuk membalikkan kemajuan signifikan yang dibuat sejauh ini dalam membatasi penyebaran penyakit virus ini.

Ulasan ini juga secara singkat memberikan gambaran tentang berbagai varian SARS-CoV-2 dan kemanjuran berbagai vaksin yang tersedia untuk pencegahan terhadap COVID-19 dan variannya.

Beberapa hal yangharus di lakukan bagi Pasien Covid 19 yaitu:

1. Pasien dan keluarga harus dididik dan didorong untuk mematuhi pedoman jarak sosial, penggunaan masker wajah dan pedoman perjalanan sesuai pedoman CDC, dan protokol jarak sosial negara bagian dan otoritas lokal yang menjaga jarak.

2. Pasien harus dididik tentang sering mencuci tangan dengan sabun dan air ketika mereka bersentuhan dengan permukaan yang terkontaminasi.

3. Pasien harus dididik dan didorong untuk mencari perawatan darurat bila diperlukan.

4. Pasien harus dididik dan diberi pilihan untuk layanan telehealth di tempat kunjungan kantor jika berlaku.

5. Pasien berisiko tinggi harus didorong untuk mencari pengobatan lebih awal dan dididik tentang pilihan pengobatan baru seperti antibodi monoklonal.

6. Pasien memerlukan pendidikan mengenai kemanjuran vaksin yang tersedia dan manfaat dari vaksinasi. 


\section{KESIMPULAN}

COVID 19 adalah salah satu jenis pandemi penyakit yang penyebabnya jenis virus corona yang reseptornya hidup di sistem pernafasan. Virus ini umumnya ditemukan pada hewan seperti kucing, sapi, unta, dan kelelewar. Untuk mencegah penyebaran pandemi penyakit ini kita harus dapat menjalankan protokoler kesehatan Covid 19 dengan baik seperti menjaga jara, mencuci tangan menggunakan pelindung tubuh seperti masker dll.

Berdasarkan program kerja yang telah dilakukan oleh mahasiswa KKM Tematik 37 UNTIRTA 2021, salah satu upaya untuk mengedukasi masyarakat umum terkait COVID-19, yaitu dengan webinar sosialisasi COVID-19 dan isolasi mandiri. Kegiatan tersebut dilakukan dalam tiga tahap, pertama yaitu tahap perencanaan (penentuan judul dan topik, penyusunan konsep dan teknis, mengundang kepala desa, camat, dan dokter sebagai pemateri), kedua yaitu tahap pelaksanaan (pelaksanaan kegiatan webinar melalui platform Zoom), dan ketiga yaitu tahap monitoring , Monitoring akan dilakukan oleh tim satgas Covid 19 Kec Solear.

Dengan kegiatan webinar masyarakat dapat teredukasi dengan baik tentang pandemi covid 19 dan cara isolasi mandiri yang baik.

\section{REFERENCE}

Dinas Kesehatan Kabupaten Tangerang (2021). Sebaran COVID-19 Kabupaten tangerang Update 24 Agustus 2021. https://covid19.tangerangkab.go.id/Di akses 24 Agustus 2020 pukl 21.26 WIB

Goldblatt, J. (2013). Special Events. New York: John Wiley and Sons.

Kemenkes RI. (2020). Pedoman Pencegahan dan Pengendalian Coronavirus Disease (Covid-19). Jakarta: Direktorat Jenderal Pencegahan dan Pengendalian Penyakit.

Safrizal A.Z., D.I Putra., S. Sofyan dan Bimo. (2020). Pedoman Umum Menghadapi Pandemi Covid-19 Bagi Pemerintah Daerah. Jakarta: Tim Kerja kementerian Dalam Negeri.

Tanu, Singhal. (2020) A Review of Coronavirus Disease-2019 (COVID19). The Indian Journal of Pediatrics (April 2020) 87(4):281-286

Yuliana. (2020). Corona Virus Diseases (Covid-19) ; Sebuah Tinjauan Literatur Jurnal Wellness And Healthy Magazine. Volume 2 Nomor 1, February 2020. 